J. Lake Sci. (湖泊科学), 2015, 27(6): 1107-1114

DOI 10. 18307/2015. 0616

(C) 2015 by Journal of Lake Sciences

\title{
太湖上游流域经济发展对废水排放及入湖总磷的影响"
}

\author{
吴 攀 ${ }^{1}$, 秦伯强 ${ }^{* *}$, 于 革, 周 健 ${ }^{1}$, 周 莉 $^{2}$ \\ (1: 中国科学院南京地理与湖泊研究所, 南京 210008) \\ (2: 常州大学石油化工学院, 常州 213164)
}

\begin{abstract}
摘 要: 为探索太湖流域水环境质量随经济发展的变化趋势, 利用环境库兹涅茨曲线模型模拟 1978-2012 年太湖上游 流域人均 GDP 与废水排放量、入湖总磷负荷的关系. 结果表明: 以 1978 年为计算基期, 太湖上游流域人均 GDP 年均增速 为 $10.3 \% \sim 11.8 \% ; 1990-2012$ 年, 太湖上游流域年均工业废水排放量和废水排放总量分别为 $64799 \times 10^{4} 、 93707 \times 10^{4} \mathrm{t}$, 与人均 GDP 均呈倒 U 型关系, 从 2006-2007 年、2008-2009 年呈下降趋势; 人湖总磷负荷与太湖上游流域废水排放总量 呈显著正相关, 且与人均 GDP 呈倒 U 型关系, 从 2007-2008 年呈下降趋势, 在 $1990 \mathrm{~s}$ 以前为 $850 \sim 1200 \mathrm{t} / \mathrm{a}, 1990 \mathrm{~s}$ 以后为 $1300 \sim 2000 \mathrm{t} / \mathrm{a}$. 该研究为从经济学角度评估太湖上游流域废水排放、人湖总磷负荷及其变化趋势提供科学依据.
\end{abstract}

关键词: 磷污染物; 人均 GDP; 环境库兹涅茨曲线; 废水排放量; 太湖上游流域

\section{Effects of economic development on wastewater discharge and influent total phosphorus load in the upstream of Lake Taihu Basin}

\author{
WU Pan ${ }^{1}$, QIN Boqiang ${ }^{1}$, YU Ge ${ }^{1}$, ZHOU $\operatorname{Jian}^{1} \&$ ZHOU Li ${ }^{2}$ \\ ( 1 :Nanjing Institute of Geography and Limnology, Chinese Academy of Sciences, Nanjing 210008, P. R. China) \\ (2:School of Petrochemical Engineering, Changzhou University, Changzhou 213164, P. R. China)
}

\begin{abstract}
In the upstream Lake Taihu Basin, economic development affects the discharge amount of wastewater and influent total phosphorus ( TP) load. In order to reveal the trend of water environment quality with economy in the Lake Taihu Basin, we simulated the relationships between wastewater discharge, influent TP load and Gross Domestic Product (GDP) per capita for the upstream Lake Taihu Basin (1978 - 2012) using Environmental Kuznets Curve (EKC) models. The results showed that the average annual growth rate of GDP per capita was $10.3 \%-11.8 \%$ based on 1978 prices in the upstream Lake Taihu Basin. Meanwhile, during 1990 - 2012, the annual mean discharge amount of industrial wastewater and the annual mean total discharge amount of wastewater were 647.99 million tons and 937.07 million tons, respectively. The export of EKC models revealed that both of industrial wastewater and total wastewater discharge had inverted-U-shaped relationships with GDP per capita, and decreased during 2006 - 2007 and 2008-2009, respectively. Moreover, influent TP load was positively related with the total wastewater discharge in the upstream of Lake Taihu Basin, presenting an inverted-U-shaped relationship with GDP per capita and declining during 2007 - 2008. During 1978 - 2012, the influent TP load ranged from $850 \mathrm{t} / \mathrm{a}$ to $1200 \mathrm{t} / \mathrm{a}$ before $1990 \mathrm{~s}$; increased to 1300 - 2000 t/a after 1990s. The EKC models provided scientific evidence for estimating wastewater discharge and the influent TP load as well as their changeable trends for the upstream Lake Taihu Basin from an economic perspective.
\end{abstract}

Keywords: Phosphorus pollutant; GDP per capita; Environmental Kuznets Curve; discharge amount of wastewater; the upstream of Lake Taihu Basin

区域经济发展对环境质量的影响引起世界范围内越来越广泛的关注, 而用经济指标来分析和预测环境 压力指标的变化也得到了研究者深人的研究和讨论. 美国经济学家 Grossman 和 Krueger 在 Kuznets 经济假

* 国家自然科学基金重点项目 (41230744) 和国家水体污染控制与治理科技重大专项 (2012ZX07101-010)联合资助. 2014-11-05 收稿;2015-02-04 收修改稿. 吴攀(1988～), 男, 博士研究生; E-mail: wupan11@ 163. com.

** 通信作者; E-mail:qinbq@ niglas. ac. cn. 
说 $^{[1]}$ 的基础上, 研究经济增长与环境变化的关系, 于 1995 年提出环境库兹涅茨曲线 (Environmental Kuznets Curve, $\mathrm{EKC}$ ) 假说, 并认为人均国民经济收人与环境污染程度存在倒 $\mathrm{U}$ 型曲线关系 ${ }^{[2]}$. EKC 表述了环境压力 随着人均国内生产总值 (Gross Domestic Product, GDP) 的增加而增长, 当经济发展到一定程度时, 随着环境的 不断改善, 环境压力不再增加并出现下降 ${ }^{[24]}$. 实证研究表明, 在不同地区由于经济发展水平和选用环境压 力指标的不同, $\mathrm{EKC}$ 还存在 $\mathrm{U}$ 型、 $\mathrm{N}$ 型、同步等关系 ${ }^{[3-5]}$, 这与当地的经济结构、科技发展和环境政策等有 关 ${ }^{[5-6]}$. 对 EKC 中环境压力指标的研究, 国外主要集中在大气质量指标 (如 $\mathrm{SO}_{2}$ 、大气悬浮颗粒物、 $\mathrm{CO}$ 、氮氧 化物等)、水环境压力指标 (如病原体、重金属、有毒化学物质等) 和其他指标 (如城市环境卫生、能源利用 等 ${ }^{[3,6]}$; 而国内多集中在工业 “三废” (如污染废气、粉尘、烟尘、工业废水、城市废弃物), 碳排放、森林资源、 农业面源污染等方面亦有研究 ${ }^{[5,7-9]}$. 研究者通过分析 EKC 的长期变化, 从经济社会学和环境政策发展等角 度对未来区域环境变化提出一定的预测, 为经济发展评估和环境管理提供服务.

在太湖流域, 改革开放以来经济增长快速, 对流域和湖泊水环境的影响也越来越大. 如 1980-2000 年, 太湖流域 GDP 增长近 8 倍, 而工业废污水排放量也增加近 1 倍 ${ }^{[10]}$; 工业、生活废水排放量从 1987 年的 $36 \times 10^{8} \mathrm{t}$ 增加至 2012 年的 $64 \times 10^{8} \mathrm{t}$, 极大地增加人河 (湖) 污染物量. 特别是人太湖总磷 ( TP) 负荷增加显 著, 在 $1960 \mathrm{~s}$ 不到 $1000 \mathrm{t} / \mathrm{a}^{[11]}$, 而 1987-1988 年为 $1988.5 \mathrm{t} / \mathrm{a}^{[12]}, 1995-2000$ 年平均达 $2000 \mathrm{t} / \mathrm{a}$ 左右 ${ }^{[13]}$, 致 使太湖水质不断下降. $1980 \mathrm{~s}$ 以来, 太湖水体 TP 浓度从 $0.020 \mathrm{mg} / \mathrm{L}$ 上升至 2000 年的 $0.120 \mathrm{mg} / \mathrm{L}$, 水质每 $5 \sim$ $10 \mathrm{a}$ 下降 1 个等级,加快湖泊富营养化及蓝藻水华的暴发 ${ }^{[10,12]}$. 而太湖上游流域为整个流域的主要集水区, 也是太湖接纳排放废水、外源营养盐的主要区域, 其人湖河道排水携带了大量工业、生活污染物, 这些污染 物包含的 TP 负荷可占人湖总量的 50\% 以上 ${ }^{[12-13]}$, 其次为农业化肥流失和养殖排污. 太湖水环境与流域经 济发展关系密切, 对这方面的研究大多为定性分析, 也有研究者对其进行 EKC 研究, 将流域内不同地区的经 济与工业 “三废” 排放量、太湖水质指标进行定量模拟 ${ }^{[14-16]}$, 得出线型、倒 U 型曲线关系. 但是前人获取的模 拟数据时间序列较短, 在新的经济和环境发展形势下需要重新考量, 而且分湖区的研究, 可能难以全面客观 衡量经济增长对整个湖泊水体水质的影响. 太湖上游流域入湖污染负荷的增加是导致近年太湖水质下降的 主要因素, 其中人湖废水和磷污染物是重要组成部分, 控制废水排放和人湖 TP 负荷成为湖泊富营养化治理 的重要措施. 但由于农业面源污染及人湖 TP 负荷的长期监测资料的缺乏, 难以估算废水排放总量及人湖 TP 负荷的变化,所以借助模型对其进行量化的模拟评估和变化分析具有重要的现实意义.

本文结合已有文献资料, 主要评估了太湖上游流域经济发展水平, 利用 EKC 定量模型模拟分析经济发 展与工业废水排放量、废水排放总量和人湖 $\mathrm{TP}$ 负荷的关系及其随时间的变化, 为太湖水环境保护和流域管 理提供参考.

\section{1 数据和方法}

\subsection{EKC 模型}

环境压力和收人的环境库兹涅茨曲线理论关系式为:

$$
y_{i t}=\alpha_{i}+\beta_{1} x_{i t}+\beta_{2} x_{i t}^{2}+\beta_{3} x_{i t}^{3}+\varepsilon_{i t}
$$

式中, $i$ 为某个区域, $y$ 为环境压力指标; $\alpha$ 为常量; $\beta$ 为待估计系数; $x$ 为对应 $i$ 区域内第 $t$ 年的人均 GDP; $\varepsilon$ 为误差项.

当 $\beta_{3}=0$ 时, 式 (1) 为典型的倒 $\mathrm{U}$ 型 $\mathrm{EKC}$ 方程, 且转变点为 $x=-\beta_{1} /\left(2 \beta_{2}\right)$. 根据前人的研究 ${ }^{[6,9]}$, 水 体指标选取二次项模型模拟效果较好. 本文选择最高次二次项的 EKC 模型对太湖上游流域的经济数据和 环境压力指标进行模拟.

\section{2 数据搜集和处理}

太湖是大型浅水湖泊, 平均水深为 $1.9 \mathrm{~m}$, 水表面积为 $2338 \mathrm{~km}^{2}$, 流域面积为 $36895 \mathrm{~km}^{2}$. 本研究区域集 中于太湖流域上游来水区, 人湖水系包括长兴水系、东西苕溪水系、宜溧河水系和武进-直湖水系, 上游流域 面积为 $19055 \mathrm{~km}^{2[12]}$, 包括常州、无锡、湖州三市行政管辖区域. 各市人均 GDP 数据、废水排放量数据的搜集 和来源见表 1. 太湖上游流域的工业废水排放量 (1990-2012 年) 、废水排放总量 (2005-2012 年) 数据为三 
市之和, 人均 GDP (1978-2012 年) 为三市 GDP 总量与总人口的比值. 太湖 TP 浓度数据年份为 1987-2012 年, 来自 “1998-2012 年太湖流域省界水体水资源质量状况通报”及 及2003-2012 年太湖流域及东南诸河水 资源公报”.太湖人湖 TP 负荷数据来自参考文献 [11-13]、[17-19]等. 本研究限于讨论随着废水排放经河 流或巷道人湖的 TP 负荷, 不包括大气降尘、降水等.

对常州、无锡、湖州和太湖上游流域的人均 GDP 与废水排放量进行 EKC 模拟, 及对太湖上游流域人均 GDP 与人湖 TP 负荷进行 EKC 模拟, 并计算开始出现下降的人均 GDP 及对应年份. 为消除通货膨胀的影 响, 以 1978 年为基期对历年人均 GDP 进行调整. 太湖上游流域人均 GDP 和湖泊年均 TP 浓度数据在拟合前 分别进行自然对数转换. 所有数据处理在 Microsoft Excel 2007 和 SPSS 13.0 软件中进行, 采用 Origin 8.0 软 件进行制图.

表 1 太湖上游流域经济发展指标和废水排放量数据来源 *

Tab. 1 Data sources of economic development indicator and wastewater discharge in the upstream Lake Taihu Basin

\begin{tabular}{|c|c|c|c|c|c|c|}
\hline \multirow{2}{*}{ 指标 } & \multicolumn{2}{|c|}{ 常州 } & \multicolumn{2}{|c|}{ 无锡 } & \multicolumn{2}{|c|}{ 湖州 } \\
\hline & 年份 & 来源 & 年份 & 来源 & 年份 & 来源 \\
\hline 人均 GDP/元 & $1978-2012$ & 1 & $1978-2012$ & 2 & $1978-2012$ & 3 \\
\hline 工业废水排放量/ $\left(\times 10^{4} \mathrm{t}\right)$ & $1986-2012$ & 1 & $1990-2012$ & 4,5 & $1990-2012$ & $3,5,6$ \\
\hline 生活废水排放量/ $\left(\times 10^{4} \mathrm{t}\right)$ & - & - & $2001-2012$ & 4,5 & $2005-2012$ & $3,5 、 6$ \\
\hline 废水排放总量/( × 104t) & $2005-2012$ & 7,8 & $2001-2012$ & 4,5 & $2005-2012$ & $3,5,6$ \\
\hline
\end{tabular}

$* 1$ 为《2013 年常州统计年鉴》; 2 为《2013 年无锡统计年鉴》; 3 为 2007-2013 年《湖州统计年鉴》;4 为 $1997-2012$ 年无 锡市环境状况公报;5 为参考文献 [16];6 为 2006-2012 年湖州市环境状况公报;7 为 2005 年常州市区环境状况公报; 8 为根据 2005 年常州地区废水排放总量资料和 2005-2012 年无锡地区工业废水排放量比例 ( 平均值为 0.633), 取 20062012 年常州地区工业废水排放量比例为 0.633 估算废水排放总量.

\section{2 结果与分析}

\section{1 太湖 TP 浓度和人均 GDP 的关系}

太湖上游流域人均 GDP 从 1978 年的 576 元增加至 2012 年的 96177 元, 2011 年无锡的 人均 GDP 率先突破 10 万元 (为 107437 元), 至 2012 年区域人均 GDP 从大到小依次为无 锡 > 常州 > 湖州 (图 1). 以 1978 年为计算基 期,在 1978-2012 年, 常州、无锡、湖州 3 个地 区的人均 GDP 增幅达 $29.4 \sim 38.1$ 倍, 年平均 增速为 $10.3 \% \sim 11.8 \%$, 其中无锡人均 GDP 年 平均增速最大, 其次为常州、湖州.

1987－2012 年,太湖年平均 TP 浓度总体 呈波动上升趋势, 从 1987 年的 $0.029 \mathrm{mg} / \mathrm{L}$ 上 升至 2012 年的 $0.071 \mathrm{mg} / \mathrm{L}$, 年平均值为 $0.091 \mathrm{mg} / \mathrm{L}$. 太湖从 1990s 开始, 水体已进人 富营养化状态. 太湖年平均 TP 浓度与上游流 域人均 GDP 的 EKC 拟合方程为 $\ln \mathrm{TP}=$

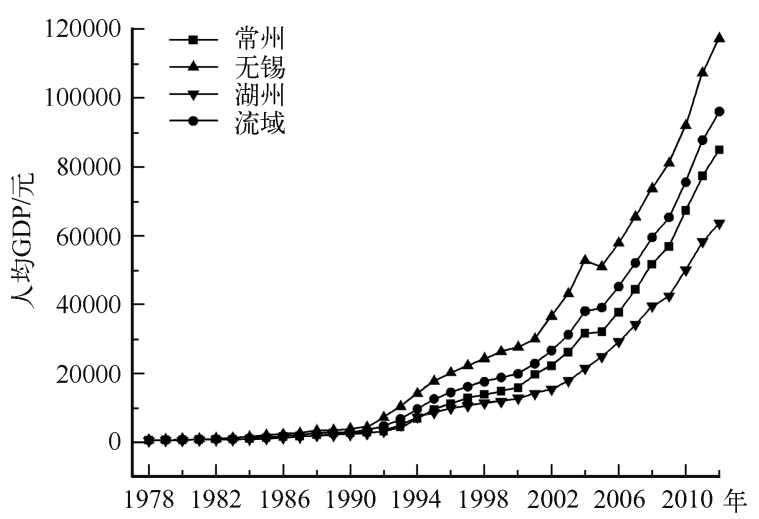

图 $11978-2012$ 年太湖上游流域人均 GDP

Fig. 1 GDP per capita in the upstream of Lake Taihu Basin during 1978-2012 $-22.64+4.67 \ln \mathrm{GDP}-0.27 \ln ^{2} \mathrm{GDP}\left(R^{2}=0.303, P<0.001\right)$, 呈倒 $\mathrm{U}$ 型曲线 (图 2). 出现下降趋势的转折 点人均 GDP 为 6216.2 元, 对应年份为 $2001-2002$ 年, 与程曦等 ${ }^{[15]}$ 预测的太湖 TP 浓度出现下降的年份 一致. 


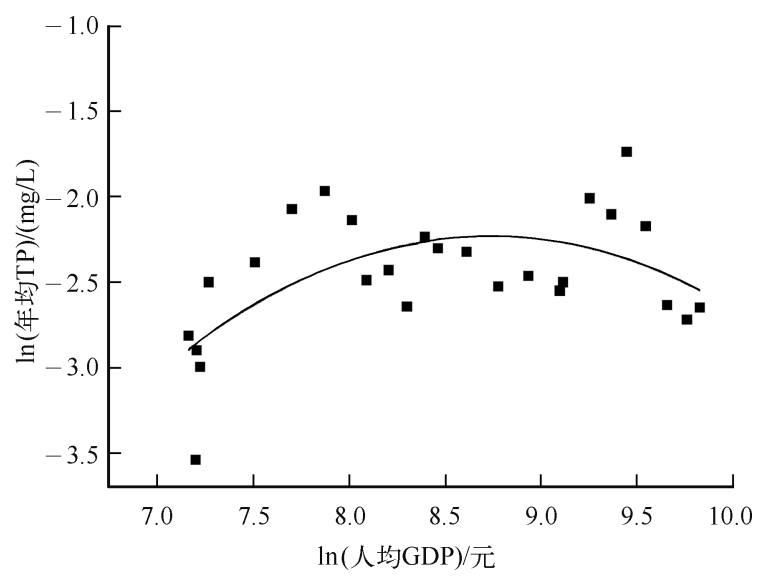

图 2 太湖年平均 TP 浓度与上游流域人均 GDP 的 $\mathrm{EKC}$ 拟合 (数据进行自然对数转换)

Fig. 2 The simulation of EKC between annual mean TP concentration of Lake Taihu and GDP per capita in the upstream of Lake Taihu Basin

\section{2 废水排放量和人均 GDP 的关系}

1990－2012 年, 太湖上游流域的年工业废 水排放量为 $37008 \times 10^{4} \sim 93036 \times 10^{4} \mathrm{t}$, 年平均 值为 $64799 \times 10^{4} \mathrm{t}$. 其中无锡的年平均工业废 水排放量最大, 为 $32813 \times 10^{4} \mathrm{t}$, 这与该地区工 业发展水平高有关, 而常州、湖州地区的年平 均工业废水排放量分别为 $22269 \times 10^{4} 、 9716 \times$ $10^{4} \mathrm{t}$. 各地区工业废水排放量与人均 GDP 的 EKC 模拟结果均达显著水平 $(P<0.001)$; 常 州、无锡的 EKC 均呈倒 U 型, 表明这 2 个区域 的工业废水排放量近年来开始出现下降趋势; 而湖州地区呈上升趋势, 表明该区域工业发展 水平仍在增长; 但上游流域的工业废水排放量 从 2011 年开始有所降低 (表 2 , 图 3 ). 从 $\mathrm{EKC}$ 模拟中计算各地区工业废水排放量开始下降 的转折点人均 GDP 及年份: 常州为 10337.2 元 (2007-2008 年); 无锡为 15744.6 元 (20062007 年); 湖州为 13875.8 元, 因超过该地区所 搜集资料的人均 GDP 最高值, 则对湖州的人均 GDP 增长采用指数模型模拟, 以 1978 年为基年, 并作为第 1 年, 则湖州人均 GDP 增长模型为 GDP $=262.59 \mathrm{e}^{0.1067 \alpha}\left(R^{2}=0.996, P<0.001\right)$, 其中 $\alpha=($ 年份 -1978$)+1$, 用此模型估算的转折点人均 GDP 对应年份为 2014-2015 年; 太湖上游流域为 11568.8 元 (2006-2007 年) (表 2). 经济发展水平高的地区对应的工业废水排放量下降年份可能提前.

2001-2012 年, 太湖上游流域年废水排放总量为 $93707 \times 10^{4} \sim 149321 \times 10^{4} \mathrm{t}$, 年平均值为 $93707 \times 10^{4} \mathrm{t}$. 常州的废水排放总量数据为根据表 1 的估算. 年均废水排放总量从大到小表现为无锡 $\left(56631 \times 10^{4} \mathrm{t}\right)>$ 常州 $\left(44404 \times 10^{4} \mathrm{t}\right)>$ 湖州 $\left(19914 \times 10^{4} \mathrm{t}\right)$. EKC 模拟中废水排放总量开始下降的人均 GDP 及年份在各地区分 别为: 常州为 11375.0 元 $(2008-2009$ 年)、无锡为 18095.1 元 $(2008-2009$ 年)、湖州为 11761.3 元 $(2012-$ 2013 年)、太湖上游流域为 12954.6 元 (2008-2009 年) (表 2, 图 4). 各区域废水排放总量下降年份比工业 废水排放量下降年份存在滞后性,一般延后 2 年左右.

表 2 太湖上游流域 1990-2012 年工业废水排放量和 2001-2012 年废水排放总量 与人均 GDP 的 EKC 拟合结果

Tab. 2 The simulations of EKC between the industrial wastewater discharge during 1990 - 2012, the total wastewater discharge during 2001-2012 and GDP per capita in the upstream of Lake Taihu Basin

\begin{tabular}{|c|c|c|c|c|c|c|}
\hline & 区域 & 拟合方程 & $R^{2}$ & $P$ & $N$ & 转折点/元 \\
\hline $1990-2012$ 年 & 常州 & $y=477.44+5.92 \mathrm{GDP}-2.86 \times 10^{-4} \mathrm{GDP}^{2}$ & 0.583 & $<0.001$ & 19 & 10337.2 \\
\hline \multirow[t]{3}{*}{ 工业废水排放量 } & 无锡 & $y=7064.38+4.32 \mathrm{GDP}-1.37 \times 10^{-4} \mathrm{GDP}^{2}$ & 0.409 & $<0.001$ & 19 & 15744.6 \\
\hline & 湖州 & $y=7582.56+0.57 \mathrm{GDP}-2.06 \times 10^{-5} \mathrm{GDP}^{2}$ & 0.382 & $<0.001$ & 19 & 13875.8 \\
\hline & 流域 & $y=14135.11+11.84 \mathrm{GDP}-5.12 \times 10^{-5} \mathrm{GDP}^{2}$ & 0.592 & $<0.001$ & 19 & 11568.8 \\
\hline $2001-2012$ 年 & 常州 ${ }^{1)}$ & $y=-93863.95+26.39 \mathrm{GDP}-1.16 \times 10^{-3} \mathrm{GDP}^{2}$ & 0.646 & $<0.001$ & 8 & 11375.0 \\
\hline \multirow[t]{3}{*}{ 废水排放总量 } & 无锡 & $y=-33217.92+10.99 \mathrm{GDP}-3.04 \times 10^{-4} \mathrm{GDP}^{2}$ & 0.743 & $<0.001$ & 12 & 18095.1 \\
\hline & 湖州 & $y=-1731.23+4.24 \mathrm{GDP}-1.80 \times 10^{-4} \mathrm{GDP}^{2}$ & 0.911 & $<0.001$ & 8 & 11761.3 \\
\hline & 流域 & $y=-107542.91+38.35 \mathrm{GDP}-1.48 \times 10^{-3} \mathrm{GDP}^{2}$ & 0.636 & $<0.001$ & 8 & 12954.6 \\
\hline
\end{tabular}

1) 常州地区 $\mathrm{EKC}$ 模拟中废水排放总量数据为估算值, 见表 1 .

\section{3 太湖入湖 TP 负荷和人均 GDP 的关系}

$2005-2010$ 年, 太湖人湖 TP 负荷 $(y)$ 与上游流域废水排放总量 $(x)$ 呈正相关关系, 线性拟合方程为 

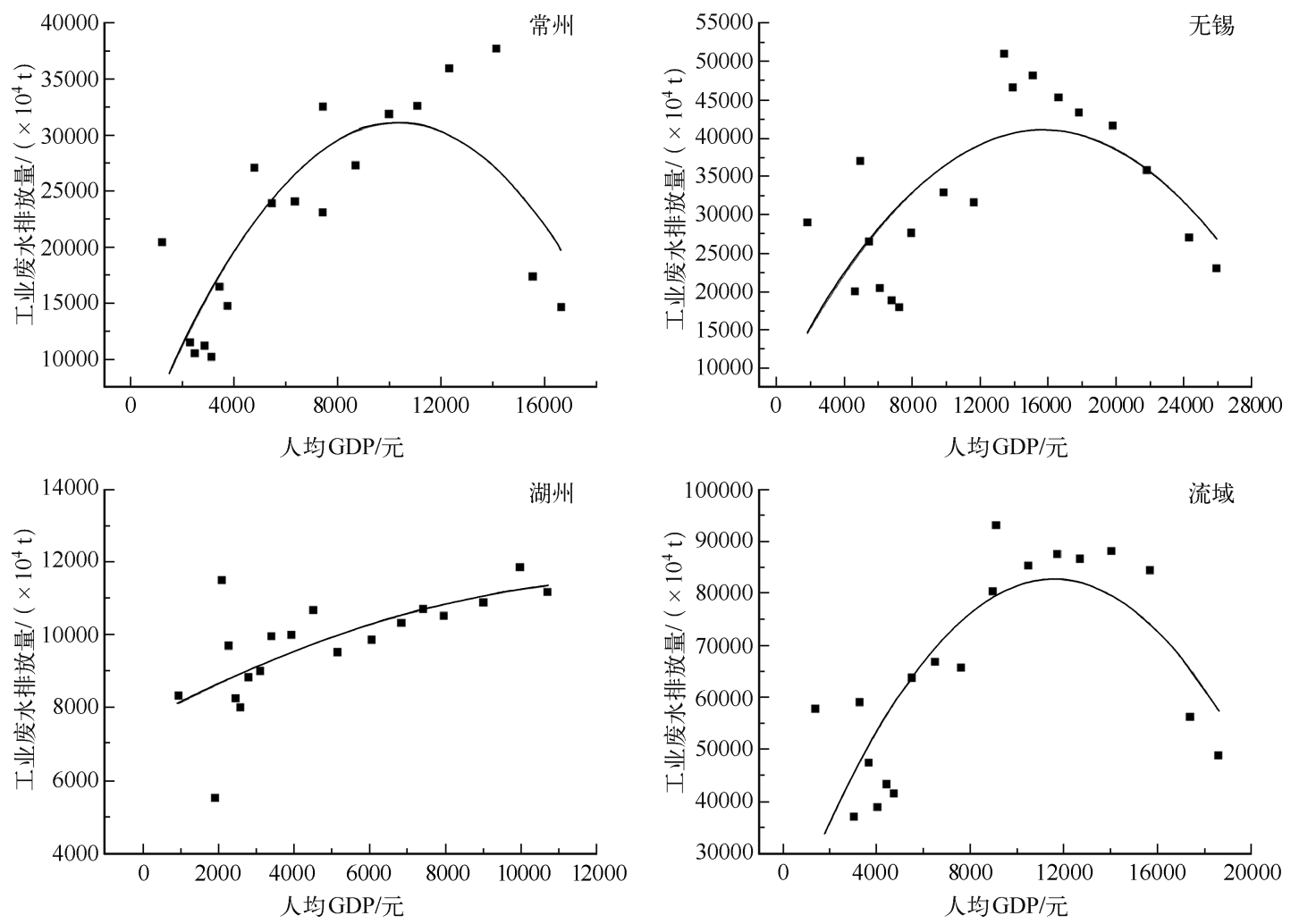

图 3 太湖上游流域工业废水排放量与人均 GDP 的 EKC 拟合

Fig. 3 The simulations of EKC between the industrial wastewater and GDP per capita in the upstream of Lake Taihu Basin

$y=-1635.66+0.0248 x\left(R^{2}=0.483, P=0.046\right)$, 表明太湖人湖 TP 负荷随着上游流域废水排放总量的增加 而呈增加趋势.

太湖人湖 TP 负荷与上游流域人均 GDP 的 EKC 拟合方程为: $y=1094.45+0.12 \mathrm{GDP}-4.67 \times 10^{-6}$ $\mathrm{GDP}^{2}\left(R^{2}=0.217, P<0.001\right)$. 前期人湖 TP 负荷随着上游流域人均 GDP 的增加而增加, 处在 EKC 倒 $\mathrm{U}$ 型 曲线前段, 但是后期特别是近年来开始下降, 且湖水 TP 浓度的下降可能也预示着人湖 TP 负荷在近年有降 低的趋势 (图 5). 模拟中人湖 TP 负荷开始下降时的人均 GDP 为 12572.8 元, 对应年份为 $2007-2008$ 年. 人湖 TP 负荷不仅受经济发展水平的影响, 也与区域经济产业结构及环境治理等因素有关 ${ }^{[3,15]}$, 这可能导致 $\mathrm{EKC}$ 拟合的 $R^{2}$ 偏低. 1990s 以前, 人湖 TP 负荷模拟值逐渐从 $850 \mathrm{t} / \mathrm{a}$ 过渡到 $1200 \mathrm{t} / \mathrm{a} ; 1990 \mathrm{~s}$ 以后, 人湖 TP 负荷一般大于 $1300 \mathrm{t} / \mathrm{a}$,最高不超过 $2000 \mathrm{t} / \mathrm{a}$.

\section{3 讨论}

\section{1 太湖上游流域人均 GDP}

人均 GDP 作为衡量区域经济发展水平的一个综合指标, 受产业结构、人口、科学技术、市场政策、国际贸 易等多种因素影响 ${ }^{[3]}$, 可用来比较不同区域的经济社会发展程度. 在本研究中, 太湖上游流域的各地区人均 GDP 及增速存在较大差异, 产业结构的不同及其发展导致经济发展水平不一. 1978-2012 年, 常州、无锡地 区均以第二产业 (工业) 为主, 比重均在 53\% 以上, 随着第一、二产业比重均向第三产业转移, 第三产业比重 在常州、无锡分别从 1978 年的 $17.4 \% 、 14.1 \%$ 上升至 2012 年的 $45.2 \% 、 43.9 \%$; 湖州地区的第二、三产业比 重分别从 1980 年的 $40.2 \% 、 19.6 \%$ 不断增加至 2012 年的 $53.4 \% 、 39.1 \%$, 第一产业比重大幅下降. 由此看 出, 太湖上游流域的经济在改革开放后, 工业、服务业快速发展, 国内生产总值不断增加, 人们的收人、生活 

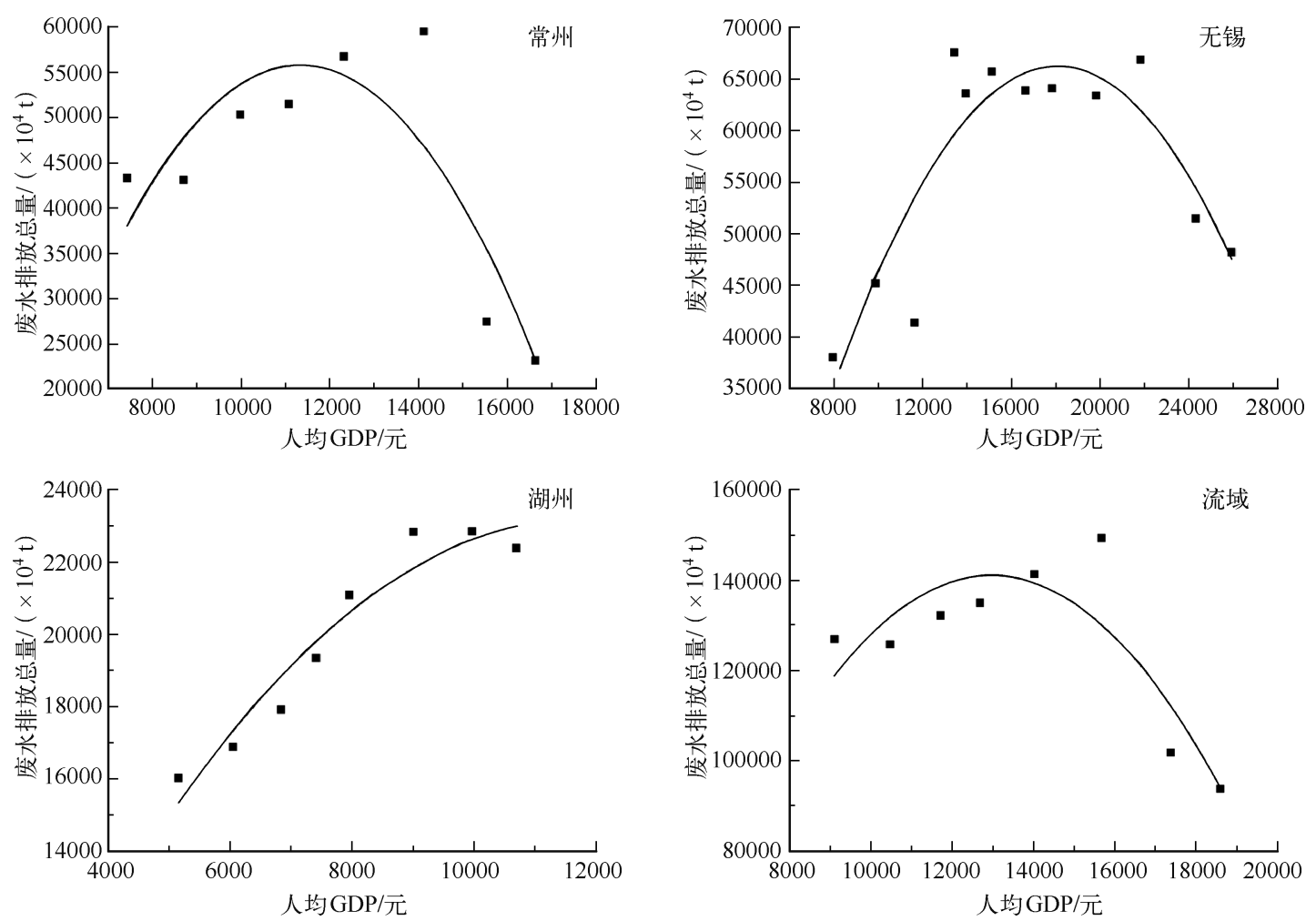

图 4 太湖上游流域废水排放总量与人均 GDP 的 EKC 拟合

Fig. 4 The simulations of EKC between the total wastewater discharge and GDP per capita in the upstream of Lake Taihu Basin

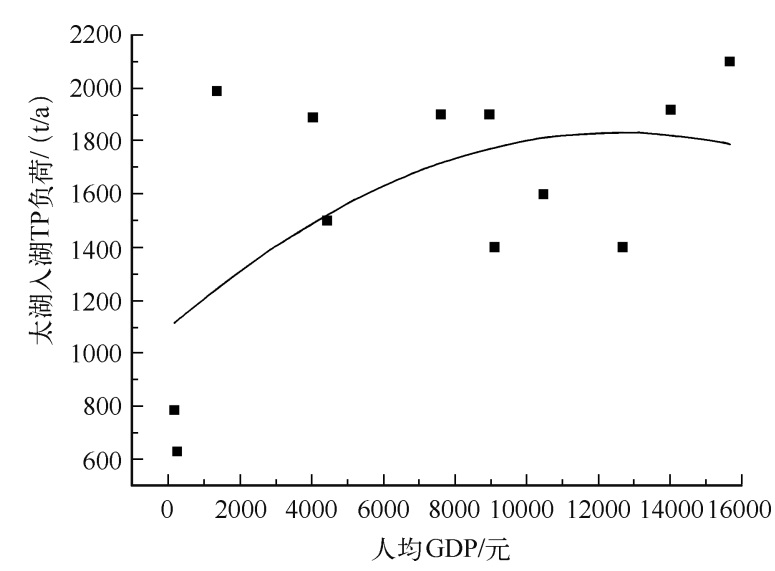

图 5 太湖人湖 TP 负荷与上游流域人均 GDP 的 EKC 拟合

Fig. 5 The simulation of EKC between the influent TP load of Lake Taihu and GDP per capita in the upstream of Lake Taihu Basin
水平也得到不断提高, 消费能力和潜力增加. 同时, 人均 GDP 考虑了人口因素, 在一定程度 上较公平地评估了不同区域的整体经济社会 发展状况. 另外, 经济发展水平的提高也意味 着更多副产品 (如工业“三废”、生活废污水、 农业化肥流失等) 产生的污染排放量相应增 加, 对环境造成愈来愈大的负面压力, 并可能 影响经济的可持续发展.

\section{2 太湖上游流域废水排放及入湖总磷}

太湖上游流域的经济在快速发展的同 时, 废水排放、人湖 TP 负荷量也在不断变化, 并影响到下游受纳水体太湖的富营养化 进程.

首先, 流域经济发展使得用水量不断增 加, 促使废水、磷污染物排放量增加. 经济发 展与资源的消耗利用与用水量紧密相关, 且 存在正相关关系 ${ }^{[2-3]}$. 太湖流域用水量从 1980

年的 $234 \times 10^{8} \mathrm{~m}^{3}$ 上升至 2012 年的 $349.5 \times 10^{8} \mathrm{~m}^{3}$, 废污水排放量从 2003 年的 $53.4 \times 10^{8} \mathrm{t}$ 上升至 2012 年的 $64.3 \times 10^{8} \mathrm{t}$, 其中第二产业和城镇居民生活废水排放占 $60 \% \sim 80 \%$,第三产业废水排放量从 2003 年的 $6.6 \times$ $10^{8} \mathrm{t}$ 大幅增至 2012 年的 $14.0 \times 10^{8} \mathrm{t}$. 太湖上游流域常州、无锡地区的工业废水排放量及废水排放总量与人 
均 GDP 呈倒 U 型关系, 表明常州、无锡的废水排放并非一直增长, 在近年已出现下降趋势. 这可能与该区域 的新能源、电子、生物医药、软件等新兴产业的稳步发展有关,使传统的机械、冶金、化工、纺织服装等废水排 放量大的行业 GDP 比重逐渐下降, 从而对人均 GDP 的贡献降低, 且愈来愈严格的环保监管和治理, 使得废 水排放随人均 GDP 升高而趋于下降. 而湖州地区的工业废水排放、废水排放总量与人均 GDP 关系为倒 U 型曲线前期, 模拟分别从 2012-2013、2014-2015 年出现下降, 比常州、无锡地区的转折时间晚, 这可能是因 为湖州是太湖流域第一产业比重最高的地区 $(8.0 \%)$, 农业用水和排水量较大, 且工业以纺织、机械、非金属 矿物制造、冶金、电力、化工等传统行业为主, 废水排放还在增长. 但从 2003 年起湖州启动了创建“全国文明 城市”、“生态市” 等工程, 随着环保投人和工业节水力度加大, 一定程度上减少了废水及污染物的排放.

而人湖 TP 主要为有机磷, 大部分来自太湖周围的城镇和农田排出的洗涤剂、杀虫剂、化肥等废污水, 其 人湖量的增加是太湖近年来 TP 负荷变幅增大的主要原因 ${ }^{[12-13,17]}$. 太湖流域工业废水排放 TP 负荷约占人湖 TP 负荷的 $16 \%$, 虽然近年来工业废水的处理一定程度上减少了磷污染物的排放, 但生活用水及废水排放量的 大幅增加、含磷化学品的大量使用, 及污水处理率不足 $20 \%{ }^{[10]}$ 等因素, 使得工业点源污染治理带来的环境改 善成效大大减弱. 但本研究考虑废水排放总量 (包含工业、生活废水排放量) 占人湖 TP 负荷的比例达 $50 \%$ 以 上 $^{[13]}$, 对其 EKC 模拟更有现实意义. 模拟中人湖 TP 负荷与上游流域废水排放总量呈显著正相关, 虽然农业 面源污染产生的 TP 排放因无资料尚未计人, 但废水排放总量、人湖 TP 负荷与人均 GDP 的 EKC 模拟均达显著 水平,所以从 $\mathrm{EKC}$ 模型的模拟统计上分析并看待人湖 TP 负荷随着经济发展变化有一定的合理性.

其次, 产业结构变化会逐渐改变废水排放量和人湖 TP 负荷. 太湖上游流域各区域以第二、三产业为主, 特别是电力、纺织、化工、冶金等制造加工业及服务行业的快速发展, 使得废水排放和人湖总磷在过去长期 增加. 而新时期下资源密集型产业不断向技术密集型产业转移, 如常州、无锡确立以新能源、新材料、节能环 保、电子信息、生物医药等为主的战略性新兴产业, 调整、优化产业结构, 湖州也在大力支持高新技术产业发 展, 同时提高工业用水效率, 使得万元工业增加值用水量不断下降, 进一步减少废水排放. 虽然研究表明太 湖上游流域的工业点源污染基本得到控制 ${ }^{[20]}$, 工业废水排放占废水排放总量比例不断下降, 但 2012 年仍超 过 $52 \%$, 且新兴的高科技产业尚处于初级发展阶段,第二产业中纺织、化工、冶金等重污染行业的污染物排 放量仍然偏高, 第三产业特别是生产型服务业发展滞后. 同时服务行业、居民生活含磷废水排放增加及农田 果园的高磷耕作方式、渔业养殖等都会增加入湖 TP 负荷 ${ }^{[12,17]}$. 所以工业废水的治理, 使得农业废水排放比 重逐渐上升,在新形势下需要重点关注和治理.

再次, 区域环境政策及保护力度的不同, 使得废水排放量及人湖 TP 负荷变化存在区域差异. 太湖上游 流域作为人湖主要集水区, 需要限制废水排放总量, 并执行严格的水污染物排放标准. 虽然常州、无锡地区 近年来加大了节水减排、黑臭河道整治、污水处理厂建设、环保执法监管力度, 但实际监测的生活废水排放 量及废水排放总量到 2011 年才有所下降, 农村生活污水治理覆盖率仍然较低, 人湖河道水质普遍较差. 如 2010 年河断面水质 $\mathrm{V}$ 类的人湖河流就包括无锡的梁溪河、直湖港, 常州的武进港、太滆运河, 主要污染因子 为 TP 和氨氮, 致使太湖北部的梅梁湾和䇥山湾污染较为严重. 湖州地区的废水排放量还未明显下降, 但工 业废水排放达标率在 2000 年以后达 95\% 以上, 随后在 2004-2006 年全面对农村环境进行重点整治, 并于 2008 年推进重点项目节能减排及建设 25 个镇级污水处理设施. 环保力度的加强使得湖州的主要人湖水质 较好, 至 2013 年连续 5 年人太湖河流断面水质保持 III 类水标准, 所以西部沿岸湖区污染相对较轻 ${ }^{[17]}$. 而太 湖流域河流水质普遍较差的现实, 如 2003-2010 年整个太湖流域河流 85\% 90\% 河长比例全年期水质劣于 III类, 更加促使了《太湖流域管理条例》的制定和实施 (自 2011 年 11 月起施行), 为保护流域内水资源和水 环境安全提供总的准则. 其中对 TP 的削减力度最大,2015 年比 2010 年削减 $22.8 \%$. 另外, 虽然 2007 年以 来太湖流域城镇污水处理能力迅速提高, 但农村污水处理设施的建设存在不足, 农业用水效率也有待提高, 需要采取工程、技术和经济等综合性节水农业措施, 严格控制农业用水量增长. 提高工业、城市生活节水, 严 格监管和减少污染排放, 加强人湖河网污水拦截和处理, 大力发展循环经济和清洁生产, 并转变农业高磷耕 作和渔业养殖方式等措施, 有利于降低废水排放及 TP 人湖量.

\section{3 环境库兹涅茨曲线模拟的适用性和局限性}

一方面, EKC 模型的选择及应用展现了一种环境与经济发展的关系, 同时提供了一种从经济发展角度 
思考湖泊水环境演变的方式. 依靠第二、三产业发展带动的经济增长, 使得污染负荷排放量快速增加, 只有 从源头控制污染排放, 转变经济增长方式, 调整产业结构, 依靠技术、政策的投人提高污染物排放标准, 从而 减少人湖污染负荷. 在经济社会较为发达的地区, 人们对环境质量的要求较高, 环境压力有在相对较低的人 均 GDP 阶段越过 EKC 下降的可能, 这也是 EKC 模拟揭示的现象, 对现实有重要的指示意义. 另一方面, $\mathrm{EKC}$ 是经验模型, 模型及环境压力指标选取的局限可能导致不同的拟合线型和变化趋势. 废水排放、人湖 $\mathrm{TP}$ 负荷和湖水 TP 浓度三者关系密切, 是太湖水环境变化的重要环境压力指标, 且均与经济指标呈倒 $\mathrm{U}$ 型 关系. 而其他指标如 COD、氨氮、总氮浓度等增加也是引起太湖水质下降的重要因素, 但含碳、氮污染物参 与地球化学循环更加复杂, 需要我们未来重点研究. 而且 EKC 模拟的准确性需依赖大量连续时间的精确样 本数据和未来监测数据的检验, 其内在解释性机理还较弱, 需要更深人的研究.

\section{4 结论}

1) 以 1978 年为计算基期,1978-2012 年太湖上游流域人均 GDP 年均增速为 $10.3 \% \sim 11.8 \%, 1987-2012$ 年太湖 TP 浓度年平均值为 $0.091 \mathrm{mg} / \mathrm{L}$, 两者 EKC 拟合表明太湖 TP 浓度从 2001-2002 年出现下降趋势.

2) 1990- 2012 年, 太湖上游流域年均工业废水排放量为 $64799 \times 10^{4} \mathrm{t}$, 年均废水排放总量为 $93707 \times 10^{4} \mathrm{t}$, EKC 拟合出现下降年份分别为 2006-2007 年、2008-2009 年.

3 ) 人太湖 TP 负荷与太湖上游流域废水排放总量呈正相关, EKC 拟合出现下降年份为 $2007-2008$ 年; 在 1978-2012 年, 人太湖 TP 负荷在 1990s 以前为 $850 \sim 1200 \mathrm{t} / \mathrm{a}$, 在 $1990 \mathrm{~s}$ 以后一般大于 $1300 \mathrm{t} / \mathrm{a}$, 最高不超 过 $2000 \mathrm{t} / \mathrm{a}$.

\section{5 参考文献}

[ 1 ] Kuznets S. Economic growth and income inequality. The American Economic Review, 1955,45(1): 1-28.

[ 2 ] Grossman GM, Krueger AB. Economic growth and the environment. Quarterly Journal of Economics, 1995,110 (2) : 353-377.

[ 3 ] Kijima M, Nishide K, Ohyama A. Economic models for the environmental Kuznets curve: A survey. Journal of Economic Dynamics \& Control, 2010,34(7): 1187-1201.

[ 4 ] 桂小丹, 李慧明. 环境库兹涅茨曲线实证研究进展. 中国人口・资源与环境, 2010,20(3): 5-8.

[ 5 ] 虞依娜,陈丽丽. 中国环境库兹涅茨曲线研究进展. 生态环境学报, 2012,21(12) : 2018-2023.

[ 6 ] Carson RT. The environmental Kuznets curve: seeking empirical regularity and theoretical structure. Review of Environmental Economics and Policy, 2010,4(1): 3-23.

[7] 刘 否, 张 敏, 喻元秀. 中国主要污染物排放的环境库兹涅茨特征及其影响因素分析. 环境污染与防治, 2010, $32(11): 107-112$.

[8] 王 谦, 高 军. 我国不同地区“环境库兹涅茨曲线”假说的检验. 科研管理, 2011,32(7): 157-164.

[9] 蒋再平. 国内环境库兹涅茨曲线数据与指标应用研究综述. 科技信息, 2011,28: 94.

[10] 靳晓莉, 高俊峰, 赵广举. 太湖流域近 20 年社会经济发展对水环境影响及发展趋势. 长江流域资源与环境, 2006, $15(3)$ : 298-302.

[11] 赖格英, 于 革. 太湖流域 1960 年代营养物质输移的模拟评估研究. 中国科学院研究生院学报, 2007,24(6): $756-764$.

[12] 秦伯强, 胡维平, 陈伟民等. 太湖水环境演化过程与机理. 北京: 科学出版社, 2004: 21-33.

[13] 赖格英, 于 革, 桂 峰. 太湖流域营养物质输移模拟评估的初步研究. 中国科学: D 辑: 地球科学, 2005,35 (S2 ) : 121-130.

[14] 储蓓蓓. 太湖流域经济增长与环境污染水平的关系研究. 环境科学与管理, 2008,33(7): 51-54.

[15] 程 䂀. 太湖水质变化与经济发展关系研究一一基于环境库兹涅茨曲线 ( EKC) 方法. 环境与可持续发展, 2012, 5: 73-77.

[16] 李 维. 湖泊环境库兹涅茨曲线是否存在? 一以太湖为例. 生态经济:学术版, 2014, (1): 363-365,370.

[17] 黄渏平. 太湖水环境及其污染控制. 北京: 科学出版社, 2001: 207-241.

[18] 燕姝雯,余 辉, 张璐璐等. 2009 年环太湖人出湖河流水量及污染负荷通量. 湖泊科学, 2011,23(6): 855-862. DOI 10. 18307/2011.0605.

[19］万晓凌,马 倩,董家根等. 江苏省人太湖河道污染物分析. 水资源保护, 2012,28(3): 38-41.

[20] 国丽珍,石敏俊, 王 否. 太湖流域农业面源污染及控制研究进展. 中国人口・资源与环境, 2010,20(1): 99-107. 